\title{
Strengthening Islamic Financial Literacy Education for Millennial Generation
}

\author{
Sufyati HS 1 \\ DOI: $10.35445 /$ alishlaH.v13I3.1290
}

Article Info

Keywords:

Education;

Islamic Financial

Literacy;

Students;

Millennial Generation

Kata kunci:

Edukasi Literasi

Keuangan Syariah

Pelajar;

Generasi Milenial

\section{Abstract}

Indonesia is one of the countries with the largest Muslim population in the world. In this era of disruption, the millennial generation is a generation that plays an important role in contributing to government programs. One of the programs launched is the development of national Islamic finance. Islamic financial literacy is needed by the financial sector to encourage economic development, both in terms of the ability to accurately manage personal finances, the business world and choices in investing. This study aims to analyze and determine the impact of strengthening Islamic financial literacy education on the millennial generation. This study uses a quantitative approach with the Wilcoxon test technique. The population in this study were college students in South Jakarta, represented by a sample of 88 respondents using purposive sampling technique. The results of the analysis using the Wilcoxon test showed that there was a significant difference in changes in students' knowledge before and after being given Islamic financial literacy counseling. Islamic financial literacy needs to be massively disseminated to all levels of society, especially universities which play an important role in financial literacy education and developing Islamic finance as part of the national economic recovery.

\begin{abstract}
Abstrak
Indonesia merupakan salah satu negara dengan penduduk muslim terbesar di dunia. Di era disrupsi ini, generasi milenial merupakan generasi yang berperan penting dalam berkontribusi terhadap program pemerintah. Salah satu program yang dicanangkan adalah pengembangan keuangan syariah nasional. Literasi keuangan syariah diperlukan oleh sektor keuangan untuk mendorong pembangunan ekonomi, baik dari segi kemampuan dalam ketepatan mengelola keuangan pribadi, dunia usaha dan pilihan dalam berinvestasi. Penelitian ini bertujuan untuk menganalisis dan mengetahui dampak dari penguatan edukasi literasi keuangan syariah pada generasi milennial. Penelitian ini menggunakan pendekatan kuantitatif dengan teknik uji Wilcoxon. Populasi dalam penelitian ini adalah mahasiswa di lingkungan kampus di wilayah Jakarta Selatan, yang diwakili dengan sampel sebanyak 88 responden dengan menggunakan teknik purposive sampling. Hasil analisis dengan uji Wilcoxon diperoleh bahwa ada perbedaan yang signifikan terhadap perubahan pengetahuan para mahasiswa sebelum dan setelah diberikan penyuluhan literasi keuangan syariah. Literasi keuangan syariah perlu disosialisasikan secara masif ke seluruh lapisan masyarakat, terutama perguruan tinggi memainkan peran penting dalam edukasi literasi keuangan dan mengembangkan keuangan syariah sebagai bagian dalam pemulihan ekonomi
\end{abstract} nasional.

${ }^{1}$ Universitas Pembangunan Nasional Veteran, Jakarta, Indonesia

Email: sufyati@upnvj.ac.id 


\section{INTRODUCTION}

Financial literacy is defined as an individual's capacity to manage money, both in terms of gathering and evaluating information intended for decision-making and recognizing the implications of the information gathered (Amagir et al., 2018). According to a 2016 OJK poll, Indonesians have a lower level of financial literacy than residents of other ASEAN countries such as the Philippines (27\%), Malaysia (66\%), Thailand (73\%), and Singapore (73\%). The low level of financial literacy is due to the increasing complexity of the financial industry, and the average person is less equipped to deal with these changes in the environment (Arceo-Gomez \& Villagomez, 2017). Government officials are anxious because they believe the general public lacks a thorough understanding of the financial principles they require. Making decisions in everyday life will be difficult due to a lack of familiarity with the situation. They will struggle to make the best economic (financial) decisions, such as taking on additional debt to supplement their income. Poor and ineffective economic management will result from incorrect decisions, which will expose people to financial crises (Huston, 2010). Individuals can also suffer losses due to financial sector crime (fraud), such as fraudulent investment fraud.

Financial literacy is a fundamental requirement for everyone to prevent financial difficulties. It is possible to experience financial troubles if there is an error in financial management (mismanagement), such as financial planning (Rapih, 2016). Financial literacy recognizes how critical it is for all people to have a basic level of financial literacy. General financial knowledge among educated people, including the millennial generation, remains at a low level, according to the Financial Literacy Index. A lack of awareness of public financial decision-making can negatively affect a country's economy (Mandell \& Klein, 2009). The low ability of the community to manage finances can be overcome through financial literacy education. Financial literacy education is one method that can improve individual skills in financial literacy (Margaretha \& Pambudhi, 2015).

The need for sharia economic education and lessons and business activities based on sharia principles is no longer a question of whether or not they are necessary; rather, they are becoming an increasingly common reality (Hafidhuddin, 2003). Economic institutions and sharia-compliant business items are sprouting and expanding in various locations around the world, including nonMuslim neighbourhoods. The training and education prepare the staff to carry out their responsibilities. Scientific studies on Islamic economics, on the other hand, continue to develop and advance (Sumadi, 2018). As a Muslim, it is necessary to apply the principles of Islamic finance as a reference in carrying out economic activities. Islamic financial management can be chosen because economic activities based on Islamic law are essentially an external economy whose starting point and goal is nothing but the pleasure of Allah SWT. Economic activities in production, consumption, exchange and distribution are linked to divine principles and divine purposes.

Islamic financial literacy in Indonesia is still very low (Fauzi \& Murniawaty, 2017), both from the formal and informal education sectors. On the other hand, Djuwita \& Yusuf (2018) explained that Islamic financial literacy is an important concept influencing a person's behaviour to adopt Islamic finance. The level of understanding of the Indonesian people towards Islamic financial service products is a significant factor in encouraging the development of Islamic finance in Indonesia and considering that Indonesia has a majority Muslim community. For this reason, Islamic financial literacy must be intensified to the community for the sake of the growing Islamic finance industry. Islamic financial literacy as a means to ground Islamic finance in Indonesia. Dropping Islamic finance must be in the proper generation (Handida \& Sholeh, 2018).

Financial literacy education is one method that can improve individual abilities in financial literacy (Huston, 2010). Financial literacy education will provide knowledge, skills, and confidence. Providing financial education regarding financial literacy will positively influence Islamic economic 
behaviour (Fernandes et al., 2014). Students who are given education about financial literacy will make students more rational in making financial decisions. The growth of the Islamic financial market is directly proportional to public awareness of the benefits of Islamic finance (Pardiansyah, 2017). Setiawati et al. (2018) define Islamic financial literacy as an aspect consisting of financial management or essential wealth and financial planning. Antara et al. (2016) stated that Islamic financial literacy consists of financial management, false transactions in debt and loan trading, investment and insurance. Rahim \& Junos (2012) explained that Islamic financial literacy is the ability, skill, and individual attitude to understand and analyze the financial information of Islamic financial institutions.

Millennials are those born in the 1980 s to 2000s. This generation is identified with advances in technology and information and all its conveniences. This generation was born during technological disruption, which on the other hand, makes it easier for them to access various kinds of information quickly (Hidayatullah et al., 2018). Millennials are the first generation to grow up with computers and the internet. The rapid development of this technology has changed the lifestyle of the millennial generation compared to the previous generation (Ningtyas, 2019). Research conducted by the Center for Strategic and International Studies in 2017 stated that millennials are more interested in sports and music activities than the activities they are interested in. In contrast to the non-millennial generation, more interested in religious activities and cooking. From the source of happiness, the millennial generation does not include financial adequacy as an indicator of their satisfaction. They are happier with the free time they have with their families, in contrast to the nonmillennial generation who pay high enough attention to their financial adequacy (CSIS, 2017).

In spending money, people will generally use it for consumption and investment. The low level of public knowledge about the financial industry and its products causes people to be easily trapped in making investments that offer lucrative profits in the short term without considering the risks (Said \& Amiruddin, 2017). Various data and research results prove how the millennial generation's lifestyle has led to a wasteful culture. Today, the majority prefer to spend their money buying cute and unique collectables, watching movies with friends, eating in cafes, and others. Millennials often don't think long in issuing their opinions so far, and there is an assumption that the millennial generation is a very wasteful group. They are indeed known as people who cannot resist various temptations, especially groceries. Apart from travelling and going to cafes to enjoy the atmosphere, the millennial generation is also labelled as less able to manage their finances (Azizah, 2020). Online stores that easily display goods with discount offers are believed to trigger their thumbs more easily to interact. With just a click, pay, the goods are sent immediately. They are also delighted to go on vacation to visit instagramable places, which of course, cost money. This fact is so contradictory that the millennial generation lives in a productive age. Supposedly, the formative period of this millennial generation should be balanced with sound financial education so that their attitudes and behaviour also show constructive attitudes and behaviour (Ali \& Purwandi, 2017).

Das' 2016 research found that 70\% of millennials in India understand financial literacy and related regulations regarding finance, credit, and loans. In America, in 2009 as many as 34\% of young adults could answer financial literacy questions correctly (De Bassa Scheresberg, 2013). In 2012, in America, Mottola (2014) also researched financial literacy in the millennial generation by $39.4 \%$ or an increase of 5.4\%. Millennials in America have received education about financial literacy as much as $36 \%$ whether in high school, college or a company. This education about financial literacy is hoped to increase understanding of financial literacy. Rosacker \& Rosacker (2015) revealed a difference before and after financial literacy training for the millennial generation; financial literacy training was higher after the millennial generation. Lusardi \& Mitchell, 2017 stated that almost all countries in the world have low financial literacy. This research focuses on the effect on the Millennial Generation of improving Islamic financial literacy education in Indonesia. As a crucial part of government programs in today's disruptive era, Millennials should be well-versed in financial matters. 


\section{METHODS}

This research was field research using a quantitative approach, carried out in a campus environment in the South Jakarta area, namely students of the Islamic Economics Study Program FEB UPN Veteran Jakarta. The sampling in this study used a purposive sampling technique, namely students who have taken Islamic Banking courses, as many as 88 students. There are 25 statements regarding the understanding of financial literacy and 20 comments on the application of Islamic financial literacy. In testing the hypothesis, this study used the Wilcoxon test because the data were not normally distributed, with dependent data conditions, the independent variable consisted of 2 pairs of categories. Finally, the shape and distribution of the data between the two paired groups was symmetrical (Sugiyono, 2012).

\section{FINDINGS AND DISCUSSION}

The data used in this study were 88 data to determine the differences in understanding Islamic financial literacy and the application. The following is descriptive data:

Table 1 Analytical Descriptive

\begin{tabular}{|c|c|c|c|c|c|}
\hline Description & $\mathbf{N}$ & Minimum & Maximum & Mean & $\begin{array}{c}\text { Std } \\
\text { Deviation }\end{array}$ \\
\hline \multicolumn{6}{|c|}{ Understanding of Islamic Financial Literacy } \\
\hline Pretest & 88 & 48 & 100 & 74.23 & 12.21 \\
\hline Posttest & 88 & 57 & 100 & 84.27 & 12.91 \\
\hline \multicolumn{6}{|c|}{ Application of Islamic Financial Literacy } \\
\hline Pretest & 88 & 2.8 & 5 & 3.83 & 0.57 \\
\hline Postest & 88 & 2.5 & 4.5 & 3.69 & 0.49 \\
\hline
\end{tabular}

Source: Researcher Processed Data (2021)

Based on table 1, it is known that the lowest understanding of financial literacy of Islamic Economic Department students is at 48 while the highest is at 100. This 48 shows an inadequate understanding of Islamic financial literacy, while a score of 100 is a heightened understanding of financial literacy. At the same time, the average knowledge of student literacy is 74.23. After participating in financial literacy training, the intermediate knowledge of student financial literacy increased to 84.27 or increased by 10.04 after participating in the movement. The average increase to 84.27 shows that the understanding of Islamic financial literacy for Islamic Economic Study Program students at UPN Veteran Jakarta has increased moderately to high. After someone understands Islamic financial literacy, it is expected to be able to apply it. From the results of the questionnaire distributed to students, it was found that the application of financial literacy with a minimum score of 2.5 or neutral. At the same time, the maximum value of 5 or strongly agrees in applying financial literacy. The average implementation of literacy before training is higher than after exercise, which is 3.83 or agrees in implementing financial literacy.

Table 2. Different Test Results

\begin{tabular}{ccc}
\hline No & Understanding & Application \\
\hline Asymp.Sign & 0.037 & 0.011
\end{tabular}

Source: Researcher Processed Data (2021)

After seeing the descriptive data, the next step is the Wilcoxon test. This test was conducted to determine the difference between 2 groups of paired data on an ordinal scale that were not normally distributed. From the results of the Wilcoxon test, it was found that the understanding of 
financial literacy before and after financial literacy training experienced differences; this was indicated by a sign of 0.037 or less than 0.05. Meanwhile, there are differences before and after financial literacy training in the application of financial literacy. This is indicated by a sign of 0.011 or less than 0.05.

Students were asked questions on their understanding or knowledge of Islamic financial institutions as part of a questionnaire on understanding Islamic financial literacy, which was distributed to them. When a student answers this question, it demonstrates their understanding of Islamic financial literacy. Before and following the Islamic financial literacy instruction, the participants were asked to complete the same questionnaire. Students' grasp of Islamic financial literacy grew by a factor of 10.04 after participating in the workshop. This demonstrates the amazing impact that the Islamic financial literacy training process has had on people's lives. The delivery style and the assignments are given to students to investigate the economic problems in their immediate environment contribute to the improvement in knowledge of Islamic financial literacy. Following that, new theories are presented to aid in comprehending Islamic financial literacy. The results of extracting information and interpreting this content revealed that most students received good or excellent grades, indicating a significant improvement in their grasp of financial literacy.

It appears that there are variations in knowing financial literacy before and after financial literacy training based on the mean value of understanding financial literacy. As determined by the results of the Wilcoxon test for understanding financial literacy, the difference between before and after participation in financial literacy training is 0.037, or less than 0.05, indicating that there is a difference between before and after participating in financial literacy training. Based on the average value, this becomes fascinating because there is an improvement in understanding of financial literacy. Krishna et al. (2010) found differences in financial literacy between business students and non-business students; business students had higher financial literacy than non-business students. This is consistent with the findings of their research. In the Management Study Program, students received valuable lessons that shaped their concept of financial literacy after participating in financial literacy training sessions. Similarly, according to Kusumawardhani et al. (2020), the presence of learning or training on comprehending financial literacy will result in students from the economics department providing better comprehension than students from other faculties. Someone who has received financial literacy expertise through training or on-campus instruction will have a certain level of financial literacy, regardless of where they learned it.

In the questionnaire on the application of Islamic financial literacy, questions were asked about the actions or applications taken by students regarding Islamic financial literacy. This application also received guidance during the Islamic financial literacy training. The mean implementation of Islamic financial literacy decreased by 0.24 after the financial literacy training. However, the application of financial literacy experienced differences before and after financial literacy training, which was indicated by the signed result of 0.011 or less than 0.05 . Understanding financial literacy without the opportunity to apply it is not enough to promote healthy financial behaviour. Friedline \& West (2016) research shows a strong relationship between financial ability and financial behaviour.

Islamic financial literacy needs to be massively disseminated to all levels of society. Training and counselling is a form of information dissemination regarding Islamic finance. The training results show an increase in Islamic financial literacy in the training participants, namely students. The participation of academics and practitioners in disseminating information is undeniable to provide the enlightenment that Islamic finance contributes to economic growth. Financial education is one of the pillars in the architecture of financial inclusion (Trimulato, 2020).

Islamic financial and economic literacy is an essential key to encouraging the growth of Islamic sharia financial institutions. Sharia economic growth still takes time compared to the development of the conventional financial industry that has already developed in Indonesia. However, it cannot be denied that the existence of Islamic financial institutions also encourages the 
development of productive sectors that are currently not served by traditional banking services. Islamic financial institutions is as a driver in efforts to accelerate the recovery of the national economy affected by the Covid-19 pandemic. This is because Islamic financial institutions have tremendous and promising potential for the financial industry and the national economy. After all, the majority of Indonesia's population is Muslim, which is closely related to the sharia system. Therefore, increasing the community's Islamic financial and economic literacy is necessary. Because in addition to having enormous market potential, increasing Islamic financial literacy is expected to attract public interest for greater use of Islamic economics (Safitri, 2021).

For sharia micro and small business actors, Islamic financial institutions can support strengthening the role of Islamic microfinance institutions. In addition, Islamic financial institutions can also encourage new sharia businesses. Using Islamic financial institutions as micro and smallscale sharia business actors can promote the global halal industry value chain macro scale. This needs to be done to spur business growth and increase the economic resilience of the people. For the community, Islamic financial institutions can make it easier for the community to be involved in various economic activities, both for transactions, investments, and other financial services. More community involvement indirect economic activities will impact economic improvement and help accelerate the recovery of the national economy affected by the Covid-19 pandemic.

In addition, the innovation of Islamic financial institutions is essential because it is related to the use of Islamic financial institutions in national Islamic economic and financial activities, and the Islamic finance industry has a large potential market. With the massive potential for economic development and Islamic finance, financial technology facilities and transaction digitization processes are needed following sharia principles. The services of Islamic sharia financial institutions and following sharia principles are also quite competitive. Payment services provided by Islamic financial institutions also include assistance in the distribution of zakat, waqf, infaq, and alms. In another form, several online sales providers also help provide sharia features to help people find halal products more efficiently. In addition, Islamic financial institutions have also been actively involved in several initiatives, including assisting the development of sharia-based MSMEs in expanding market access and developing transaction capacity. This means that community involvement through Islamic sharia financial institutions can drive economic development and Islamic finance as pillars of the national economy.

Implementing teaching and learning at the university level is more than just academic learning. Not a few students are trying to survive to be more independent in financial independence, independence from daily life, friendship life, organization, and community life to mature themselves. Not to mention that students are also required to get a sufficient predicate from the academic side so that the learning process in higher education can be completed on time. Surviving financial independence is not easy; managing finances obtained from parents or scholarship providers can be used as tuition payments, paying rent for housing, paying for food, and setting aside money for other things. Looking for additional funds by working on the sidelines of lectures to cover all the costs needed is an option so that a student's choice to become a person who is more independent from all sides can be realized.

Students get information about Islamic financial literacy through courses, socialization, seminars, or conversations with family or friends. A college is a place of a learning center for all students. Increasing financial knowledge for students must be an effort by universities so that every student can be well literate about finances so that students are not wrong in determining steps related to decision making in financial management. The financial management of an individual can be analyzed through four aspects. The first aspect is that the use of funds, inputs and outputs of financial management must be following the targets and based on current needs and future benefits. The second aspect is determining the source of funds. For students, the source of funds can come from parental gifts, scholarships, donors or funds generated by the students themselves through work obtained from their efforts. The following third aspect is risk management; preparation for 
unpredictable events such as the arrival of a disaster is a financial arrangement that needs to be prepared for every student. Finally, the fourth aspect is future planning. Careful planning regarding financial management is done by a student so that the funds obtained can be helpful for the future. Whether or not a student makes an investment that has previously conducted a study of the right financial products and services following the objectives of financial management.

According to Chen \& Volpe (1998), the basic things that must be understood in one's knowledge of sound financial literacy include four things. The first is General Financial Knowledge, which provides a general understanding of finance. Here is an understanding of personal finance, an understanding of lease agreements, assets, income and expenditure patterns, savings account reconciliations, net worth calculations, and personal financial planning, credit and tax deductions. The second thing is Savings and Loans; These aspects include creditworthiness, sources of customer credit reports, deposit insurance, checking account overdrafts, double interest, certificates of deposit requirements, loan signature consequences, annual percentage rates and credit card usage. The third basis in understanding financial literacy is insurance which includes determining car insurance rates, reasons for buying insurance, characteristics of health insurance, conflict resolution of insurance, characteristics of homeownership insurance and characteristics of term insurance. And the last is an investment. This investment includes choosing the suitable mutual funds, investing in stocks for the investment purpose that is usually chosen, the benefits of early retirement as an initial investment, high returns are always followed by high risk, changes in interest rates and treasury bond prices, regional bond investments, on average.Average fees on exchange rates, investment diversification, mutual fund fees, foreign exchange rates and mutual fund ownership characteristics. The above description of the four basic things that a student must have to be said to be well literate is quite complex. The level is very complicated compared to the literacy level of students in Indonesia.

Studies on Muslim students in Bogor found that the factors influencing their level of Islamic financial literacy included: developing regular savings patterns, writing financial goals and budgets to help students reach their financial goals, and planning how they will use the money they have. One of the second indicators, financial knowledge, deals with sharia-compliant Islamic financial knowledge, including the roles of the supervisory board and the sharia-compliant banking contracts (wadi'ah), as well as how to calculate the percentage of profit-sharing and determine the total income. A lack of Islamic financial literacy among students has prompted government initiatives to improve financial literacy and inclusion for the entire community, not just students. In order to work with Indonesia's formal financial institutions, such as OJK, Bank Indonesia, and related ministries to achieve literacy and financial inclusion goals, university campuses must act as a bridge between the government and the community by holding training, seminars, and community service projects.

As described above, promoting financial literacy necessitates the involvement of a wide range of parties, including the federal government, financial institutions, and academic institutions. To achieve the expected level of financial literacy in Indonesia, it is necessary that each individual encourages himself to continue reading, learning, and obtaining as much precise information as possible before making the decision-making steps in financial management. The community's efforts to improve its knowledge of Islamic finance, which were initially adequate for someone with a basic $m$ understanding of Islamic finance, improved its knowledge of Islamic finance significantly. According to Islamic financial management objectives, individuals and the entire community can choose Islamic financial products and services based on their needs, properly understand the benefits of and risks associated with these options, fully comprehend their responsibilities as well as those of the financial institutions they choose to use and believe that the products and services selected financial institutions can improve their welfare based on Sharia principles.

Knowledge of the benefits and risks, correctly understanding the rights and obligations related to the requirements in determining financial products and services must be the main focus for students in particular and the broader community in determining their financial management so that in the future, the existing funds will be of benefit. It is also essential to prevent unwanted things 
from happening, such as losses or the selection of financial product services that have not been registered with the OJK, which results in loss of funds without any accountability from the service provider. Therefore, increasing the financial literacy index for students also provides significant benefits to the service sector and financial institutions in Indonesia in particular.

\section{CONCLUSION}

Based on the research that has been done, it can be concluded that the strengthening of Islamic financial literacy education for the millennial generation, which in this case represented by a group of students experiencing differences before and after Islamic financial literacy education is carried out. There is a significant difference in changes in students' knowledge before and after being given Islamic financial literacy counseling. The enhancement in students' ability to manage finances, especially sharia-based one, will motivate the public to understand Islamic financial literacy widely and can be applied in managing their finances. The role of universities is very vital in providing education to students in understanding Islamic financial literacy. Therefore, it is expected to be able to encourage to increase literacy in all aspects. In the future, the development of Islamic financial literacy education is expected not only to students majoring in economics. Still, it is likely that it will develop to all students so that it can be transmitted to the entire community to understand the importance of Islamic financial literacy education.

\section{REFERENCES}

Ali, H., \& Purwandi, L. (2017). Milenial Nusantara. Jakarta: Gramedia Pustaka Utama.

Amagir, A., Groot, W., Maassen van den Brink, H., \& Wilschut, A. (2018). A review of financialliteracy education programs for children and adolescents. Citizenship, Social and Economics Education, 17(1), 56-80.

Antara, P. M., Musa, R., \& Hassan, F. (2016). Bridging Islamic Financial Literacy and Halal Literacy: The Way Forward in Halal Ecosystem. Procedia Economics and Finance, 37, 196-202.

Arceo-Gomez, E. O., \& Villagómez, F. A. (2017). Financial Literacy Among Mexican High School Teenagers. International Review of Economics Education, 24, 1-17.

Azizah, N. S. (2020). Pengaruh Literasi Keuangan, Gaya Hidup pada Perilaku Keuangan pada Generasi Milenial. Prisma (Platform Riset Mahasiswa Akuntansi), 1(2), 92-101.

Centre for Strategic and International Studies. (2017). Ada Apa dengan Milenial? Orientasi Sosial, Ekonomi dan Politik. In Survei Nasional CSIS 2017.

Chen, H., \& Volpe, R. P. (1998). An Analysis of Personal Financial Literacy Among College Students. Financial Services Review, 7(2), 107-128.

Das, S. C. (2016). Financial Literacy Among Indian Millennial Generation and Their Reflections on Financial Behaviour and Attitude: An Explanatory Research. T Indian Journal He of Commerce, 69(4).

Djuwita, D., \& Yusuf, A. A. (2018). Tingkat Literasi Keuangan Syariah Di Kalangan UMKM Dan Dampaknya Terhadap Perkembangan Usaha. Al-Amwal: Jurnal Ekonomi dan Perbankan Syari'ah, 1O(1).

Fauzi, A., \& Murniawaty, I. (2020). Pengaruh Religiusitas dan Literasi Keuangan Syariah Mahasiswa terhadap Minat Menjadi Nasabah di Bank Syariah. Economic Education Analysis Journal, 9(2), 473-486. 
Fernandes, D., Lynch Jr, J. G., \& Netemeyer, R. G. (2014). Financial Literacy, Financial Education, and Downstream Financial Behaviors. Management Science, 6o(8), 1861-1883.

Friedline, T., \& West, S. (2016). Financial Education Is Not Enough: Millennials May Need Financial Capability to Demonstrate Healthier Financial Behaviors. Journal of Family and Economic Issues, 37(4), 649-671.

Hafidhuddin, D. (2003). Manajemen Syariah dalam Praktik. Gema Insani.

Handida, R. D., \& Sholeh, M. (2018). Pengaruh Tingkat Pengetahuan, Kualitas Layanan, dan Tingkat Literasi Keuangan Syariah Terhadap Pengambilan Keputusan Masyarakat Muslim Menggunakan Produk Perbankan Syariah di Daerah Istimewa Yogyakarta. Jurnal Ekonomi dan Pendidikan, 15(2), 84-90.

Hidayatullah, S., Waris, A., \& Devianti, R. C. (2018). Perilaku Generasi Milenial dalam Menggunakan Aplikasi Go-Food. Jurnal Manajemen Dan Kewirausahaan, 6(2), 240-249.

Huston, S. J. (2010). Measuring Financial Literacy. Journal of Consumer Affairs, 44(2), 296316.

Krishna, A., Rofaida, R., \& Sari, M. (2010). Analisis Tingkat Literasi Keuangan Di Kalangan Mahasiswa Dan Faktor-Faktor Yang Mempengaruhinya (Survey pada Mahasiswa Universitas Pendidikan Indonesia). In Proceedings of the 4th International Conference on Teacher Education (Vol. 4, No. 1, pp. 552-560).

Kusumawardhani, R., Cahyani, P. D., \& Ningrum, N. K. (2020). Analisis Perbedaan Tingkat Literasi Keuangan antara Mahasiswa Fakultas Ekonomi dan Mahasiswa Fakultas Non Ekonomi. Jurnal Ilmiah Manajemen, 10(9), 15-28.

Lusardi, A., \& de Bassa Scheresberg, C. (2013). Financial Literacy and High-Cost Borrowing in The United States (No. W18969). National Bureau of Economic Research.

Lusardi, A., \& Mitchell, O. S. (2017). How Ordinary Consumers Make Complex Economic Decisions: Financial Literacy and Retirement Readiness. Quarterly Journal of Finance, 7(03), 1750008.

Mandell, L., \& Klein, L. S. (2009). The Impact of Financial Literacy Education on Subsequent Financial Behavior. Journal of Financial Counseling and Planning, 2O(1).

Margaretha, F., \& Pambudhi, R. A. (2015). Tingkat Literasi Keuangan Pada Mahasiswa S-1 Fakultas Ekonomi. Jurnal Manajemen dan Kewirausahaan, 17(1), 76-85.

Mottola, G. R. (2014). The Financial Capability of Young Adults-A Generational View. FINRA Foundation Financial Capability Insights, 1-12.

Ningtyas, M. N. (2019). Literasi Keuangan pada Generasi Milenial. Jurnal Ilmiah Bisnis Dan Ekonomi Asia, 13(1), 20-27.

Pardiansyah, E. (2017). Investasi dalam Perspektif Ekonomi Islam: Pendekatan Teoritis dan Empiris. Economica: Jurnal Ekonomi Islam, 8(2), 337-373.

Puspita, A. T., Lubis, D., \& Muthohharoh, M. (2021). Faktor-Faktor yang Memengaruhi Tingkat Literasi Keuangan Syariah pada Mahasiswa Muslim di Bogor. AL-MUZARA'AH, 9(1), 1-20.

Rahim, N. A., \& Junos, S. (2012). The Halal Product Acceptance Model for The Religious Society. Business and Management Quarterly Review, 3(1), 17-25.

Rapih, S. (2016). Pendidikan Literasi Keuangan Pada Anak: Mengapa dan Bagaimana? Scholaria: Jurnal Pendidikan dan Kebudayaan, 6(2), 14-28.

Rosacker, K. M., \& Rosacker, R. E. (2016). An Exploratory Study of Financial Literacy Training for Accounting and Business Majors. The International Journal of Management Education, 14(1), $1-7$.

Safitri, T. A., Asnaini, A., \& Idwal, I. (2021). The Role of Islamic Commercial Banks in the Recovery of the National Economy Affected by the Pandemic in Indonesia. Journal of Indonesian Management (JIM), 1(3), 323-331.

Said, S., \& Amiruddin, A. M. A. (2017). Literasi Keuangan Syariah di Perguruan Tinggi Keagamaan Islam (Studi Kasus UIN Alauddin Makasar). Al-Ulum: Jurnal Studi Islam, 17(1), 44-64. 
Setiawati, R., Nidar, S. R., Anwar, M., \& Masyita, D. (2018). Islamic Financial Literacy: Construct Process and Validity. Academy of Strategic Management Journal, 17(4), 1-12.

Sugiyono. (2011). Metode Penelitian Kuantitatif Kualitatif Dan R\&D. Bandung: Alfabeta.

Sumadi, S. (2018). Peran Pendidikan dan Pengenalan Sistem Ekonomi Syariah Kepada Generasi Muda di Era Perkembangan Ekonomi Syariah. Jurnal Ilmiah Edunomika, 2(02).

Trimulato, T. (2020). Akselerasi Tingkat Pengetahuan Mahasiswa Tentang Sistem dan Produk Perbankan Syariah Melalui Media Online Pada Program Studi Perbankan Syariah Uin Alauddin Makasar. Ekspansi: Jurnal Ekonomi, Keuangan, Perbankan, dan Akuntansi, 12(1), 12-30. 